\title{
Expanded perlite: potential for removing antibiotics from water
}

\author{
Bruna Martins Vicentin' and Raquel Dalla Costa da Rocha' \\ 'Chemistry Department, Universidade Tecnológica Federal do Paraná, Pato Branco 85503-390, Brazil
}

This work aims to study the potential of expanded perlite (EP) for amoxicillin (AMX) removal in aqueous solution. For this purpose, chemical, morphological, and textural characteristics of the EP were evaluated, in addition to $A M X$ removal by the adsorption process. The kinetic, isothermal, and thermodynamic parameters were also assessed. The EP presented an isoelectric point of 6.5 and a surface with hydroxyl bands, which favour the adsorption process. Air bubbles were sealed and randomly connected with each other, increasing the surface area relative to the adsorption sites. These non-porous or macro-porous sites demonstrate efficiency in the mechanisms of mass transfer. AMX removal was determined to be a pseudo-second-order process since the adsorption velocity was proportional to the square of the available adsorption sites and indicates heterogeneity in the surface interactions between the adsorbed molecules. Also, the interactions were considered multilayer for low concentrations and monolayer for high concentrations (Sips isotherm). The adsorption process was endothermic and utilised a physical adsorption mechanism. Considering that no modification treatment was applied to the EP, and due to its neutral isoelectric point, macropores, amorphous and dipole induction force (physical adsorption) characteristics, favourable affinity between EP and $\mathrm{AMX}$ was observed.

\section{INTRODUCTION}

Perlite is a natural glassy volcanic rock (composition: $\cong 75 \%$ of $\mathrm{SiO}_{2} ; \cong 15 \%$ of $\left.\mathrm{Al}_{2} \mathrm{O}_{3}\right)(\mathrm{Ghassabzadeh}$ et al., 2010; Cabuk et al., 2018; Corregidor et al., 2019), termed expanded perlite (EP) after being rapidly heated for $760-1200^{\circ} \mathrm{C}$ and consequently expanded up to 20 times its original volume (Alkan and Dogan, 2002; Cabuk et al., 2018; De Oliveira et al., 2019). EP is employed in the construction industry (Papa et al., 2018; Leyton-Vergara et al., 2019; Top et al., 2020; Jiang et al., 2020), composite structure (Rodriguez et al., 2016; Ma et al., 2020; Rathore et al., 2020), agriculture and environmental sectors (Villaseñor et al., 2011; Torab-Mostaedi et al., 2011; Díez et al., 2020).

In the environmental sphere, the use of EP is efficient in removal of pollutants, such as heavy metals (Ghassabzadeh et al., 2010; Torab-Mostaedi et al., 2010; Torab-Mostaedi et al., 2011; Silber et al., 2012; Cabranes et al., 2018; Temel, 2018; Turp, 2018), petroleum hydrocarbons (Moussavi and Bagheri, 2012), among others (Heydartaemeh et al., 2014; Almeida et al., 2017; Da Silva Filho et al., 2018). EP has been studied for cetyltrimethylammonium bromide (Alkan et al., 2005), ciprofloxacin and isoniazid (Dube et al., 2018) drug removal. However, no previous studies have been reported on the use of EP for removal of amoxicillin in water.

Water contaminated by drug residues is problematic, since these residues affect human biological activities (Ali et al., 2016; Luo et al., 2018). Some water contaminants include analgesic, antiinflammatory, and antibiotic drugs (Luo et al., 2018). Regarding antibiotics, the main concern is antibiotic resistance due to the reduction in treatment effectiveness for an ever-increasing range of infections caused by bacteria (WHO, 2014; Yu et al., 2020). Increasingly, scientists all over the world are on the alert for this serious public health problem.

The antibiotics contaminate the environment through pharmaceutical, domestic and hospital effluents that spread antibiotic at trace concentrations to drinking water, mainly as a result of the drainage and/or water furnishing system (surface water) (Ul Ain et al., 2018).

Amoxicillin $\left(\mathrm{C}_{16} \mathrm{H}_{19} \mathrm{~N}_{3} \mathrm{O}_{5} \mathrm{~S}\right)$ (AMX) is a broad-spectrum antibiotic derived from amino penicillin ( $\beta$-lactam antibiotic). AMX is considered to be one of the most consumed antibiotics throughout the world, being prescribed to treat both human and animal infections (Githinji et al., 2011; Ul Ain et al., 2018).

The objective of this work was to study the potential of EP as an adsorbent in AMX removal and to evaluate the kinetic, isothermal, and thermodynamic parameters of the adsorption process.

\section{METHODS}

\section{Antibiotic}

AMX (98\% in purity) was purchased from a manipulation pharmacy. Deionized water was employed to obtain the AMX stock solution $\left(50 \mathrm{mg} \cdot \mathrm{L}^{-1}\right)$.

Then the AMX solution was scanned by UV-VIS spectrophotometer (Thermo Scientific Evolution $60 S)$ in the range $200-400 \mathrm{~nm}$ using deionized water as blank. The wavelength corresponding to maximum absorbance $\left(\lambda_{\max }\right)$ was found to be $223 \mathrm{~nm}$.

CORRESPONDENCE

Raquel Dalla Costa da Rocha

EMAIL

raqueldcr@utfpr.edu.br

\section{DATES}

Received: 8 April 2020

Accepted: 30 September 2021

\section{KEYWORDS}

aluminosilicate

amoxicillin

adsorption

characteristics

mathematic modelling

\section{COPYRIGHT}

(c) The Author(s)

Published under a Creative Commons Attribution 4.0

International Licence

(CC BY 4.0) 
For the calibration curve, the stock solution was diluted to obtain a concentration ranging from 5 to $50 \mathrm{mg} \cdot \mathrm{L}^{-1}$. The relation between AMX concentration and absorbance presented linearity $\left(r^{2}=0.999\right)$.

\section{EP obtention and characterization}

EP was received from Imerys - Perlite Paulínia Minerais Ltda, São Paulo, Brazil. The perlite was extracted from the Tucumán quarry in the province of Salta, Argentina. The expansion process was carried out in an oven at $900^{\circ} \mathrm{C}$ at the industrial unit of Banda del Río Salí, Argentina.

The isoelectric point of EP was determined by powder addition according to Mullet et al. (1997) with modifications. EP (50 mg) was added to $50 \mathrm{~mL}$ of $\mathrm{NaCl}$ solution $\left(0.1 \mathrm{~mol} \cdot \mathrm{L}^{-1}\right)$, with the $\mathrm{pH}$ previously adjusted from 2 to 13 with $\mathrm{HCl}\left(0.1 \mathrm{~mol} \cdot \mathrm{L}^{-1}\right)$ and $\mathrm{NaOH}$ $\left(0.1 \mathrm{~mol} \cdot \mathrm{L}^{-1}\right)$. After $24 \mathrm{~h}$ with constant agitation $\left(180 \mathrm{r} \cdot \mathrm{min}^{-1}\right)$ and temperature $\left(25 \pm 2^{\circ} \mathrm{C}\right.$ ) (Shaker Mod MAQL-200), the final $\mathrm{pH}$ was measured in triplicate.

Infrared (IR) spectral data were taken from a PerkinElmer FTIR Frontier spectrophotometer $\left(400-4000 \mathrm{~cm}^{-1}\right)$ at $2 \mathrm{~cm}^{-1}$ resolution, using $\mathrm{KBr}$ pellets containing $\mathrm{EP}$ in the proportions of 99:1 mg. The X-ray diffractometry was determined using a diffractometer (XRD-Rigaku Mini flex 600). Finely ground samples of EP were dispersed onto the copper $(\mathrm{Cu})$ sample holder and the data were collected from 3 to $90^{\circ}$ with a step size of $0.05^{\circ}$ and $1 \cdot \mathrm{s}^{-1}$ scanning speed.

In order to verify the morphology of the EP particles, a scanning electron microscope (SEM) (Hitachi TM3000) at 500x magnification was employed. The sample was previously exposed to thermal treatment at $300^{\circ} \mathrm{C}$, for $24 \mathrm{~h}$ under vacuum to remove water, and the analyses were performed at $77 \mathrm{~K}$ using liquid nitrogen. Surface area measurement was performed by adsorption using nitrogen as adsorbate (Quantachrome NOVA 2000e).

\section{EP potential for AMX removal}

The experiments were carried out in a batch system. The triplicate assays were conducted in a bench orbital shaker at $28 \pm 2^{\circ} \mathrm{C}$ and $150 \mathrm{r} \cdot \mathrm{min}^{-1} .1 \mathrm{~g}$ of EP was added to $100 \mathrm{~mL}$ AMX solution ( $\mathrm{pH} 4.0$; concentration: $50 \mathrm{mg} \cdot \mathrm{L}^{-1}$ ). At the end of each batch, the supernatant was set apart from solid material by filtration (Whatman $-\mathrm{n}^{\circ} 1$ ) and centrifugation $\left(3000 \mathrm{r} \cdot \mathrm{min}^{-1} ; 5 \mathrm{~min}\right.$ ) and submitted to spectrophotometric analysis at $223 \mathrm{~nm}$ to AMX determination.

Adsorption kinetics assays were conducted by AMX quantification from an aliquot of supernatant at each time frame.

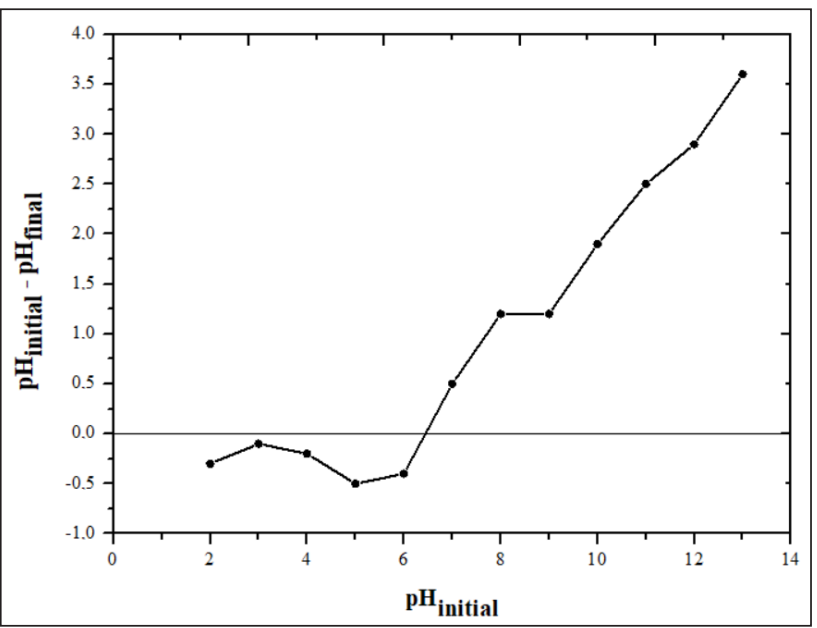

Figure 1. Isoelectric point of EP
The experimental data were fitted to pseudo-first-order (Yener et al., 2006) and pseudo-second-order (Blanchard et al., 1984) equations. The adsorption isotherm assay was performed for AMX concentrations of 5, 20, 35, and $50 \mathrm{mg} \cdot \mathrm{L}^{-1}$. Experimental data obtained for adsorption equilibrium studies were fitted to Langmuir (Langmuir, 1916), Freundlich (Freundlich, 1909) and Sips (Sips, 1948) isothermal models. The thermodynamic adsorption parameters were determined according to Gibbs free energy and Arrhenius equations from the adsorption equilibrium constant (Han et al., 2005), repeated at $25,30,35$, and $40^{\circ} \mathrm{C}$.

\section{RESULTS AND DISCUSSION}

\section{EP characterization}

The mineral EP used as adsorbent was previously characterized by textural, morphological, and functional group analyses.

As demonstrated in Fig. 1, the isoelectric point of EP was found to be 6.5 , which indicates its capacity to be positively or negatively charged according to the medium $\mathrm{pH}$.

Alkan et al. (2006) and Ghassabzadeh et al. (2010) found isoelectric points of 6.6 and 6.5, respectively. Alkan et al. (2005) confirmed the presence of silanol groups on EP, explaining that $\mathrm{H}^{+}$ions can be replaced by $\mathrm{Si}-\mathrm{OH}$ and $\mathrm{Al}-\mathrm{OH}$ groups. This way, the acidic and alkaline properties of EP are attributed to the protonation and deprotonation of these groups. Although low and high $\mathrm{pH}$ values give rise to cationic and anionic complexes, respectively, the breaking up of $\mathrm{O}-\mathrm{H}$ led to an increase in the negativity of the surface (Putra et al., 2009).

The main chemical groups identified in EP adsorbent for AMX removal are shown in Fig. 2.

The sample showed characteristic bands of the mineral. The broad band $\left(3626 \mathrm{~cm}^{-1}\right)$ between 3450 and $3600 \mathrm{~cm}^{-1}$ was attributed to stretching vibrations of $-\mathrm{OH}$ groups on the surface of $-\mathrm{Si}-\mathrm{OH}$. The band at $1641 \mathrm{~cm}^{-1}$ was attributed to the bending mode of $\mathrm{O}-\mathrm{H}$ from water molecules. The intense band at $1061 \mathrm{~cm}^{-1}$ was associated with the stretching vibrations of $\mathrm{Si}-\mathrm{O}-\mathrm{Si}$ structures. The bands at 783 and $454 \mathrm{~cm}^{-1}$ were attributed to the stretching vibrations of $\mathrm{Si}-\mathrm{O}$ and $\mathrm{Al}-\mathrm{O}$, respectively.

Similar results were reported for EP by Nasrollahzadeh et al. (2015), Cabuk et al. (2018), and De Oliveira et al. (2019). The interfaces of mineral particles are usually covered with hydroxyl groups formed by dissociative chemisorption of water. These groups act as effective adsorptive sites (Liu et al., 2017). This feature may be used as a guideline to obtain satisfactory adsorption results for EP in removing AMX. 
The XRD pattern and SEM of the EP sample are presented in Fig. 3.

The main peaks for EP were $\mathrm{SiO}_{2}-23.0^{\circ}$ and $29.1^{\circ}$ (Fig. 3a), classified in the ICSD database as characteristic of $\mathrm{n}^{\circ} 00-029-005$ (silicon oxide) and $\mathrm{n}^{\circ}$ 01-085-0462 (quartz), respectively. This reflects the composition of the EP, of which silicon oxide constitutes $75 \%$, with the rest made up of impurity phases, speculated to be aluminosilicate compounds in the structure (Tian et al., 2019). Also, through the XRD pattern results, EP was shown to be essentially amorphous, which is in accordance with literature (Celik et al., 2013; Almeida et al., 2017; De Oliveira et al., 2019).

The EP sample presented characteristic holes and thin walls (Tian et al., 2019; De Oliveira et al., 2019), an arrangement resulting from the perlite expansion process, in which the air bubbles are sealed and randomly connected to each other, increasing the relative surface area of the sites. This was confirmed by BET (Fig. 4, which presented a Type II isotherm curve (IUPAC, 1985), typical of material that has been submitted to a thermal expansion process (De Oliveira et al., 2019; Corregidor et al., 2019). The surface area of EP was found to be $1.6 \mathrm{~m}^{2} \cdot \mathrm{g}^{-1}$. Other investigators have reported surface areas of $1.8 \mathrm{~m}^{2} \cdot \mathrm{g}^{-1}$ (Ghassabzadeh et al., 2010), $1.7 \mathrm{~m}^{2} \cdot \mathrm{g}^{-1}$ (Nasrollahzadeh et al., 2015), and $2.0 \mathrm{~m}^{2} \cdot \mathrm{g}^{-1}$ (Corregidor et al., 2019).

\section{Physicochemical aspects of AMX removal by EP}

The amount of AMX adsorbed by EP increased rapidly in the first $7 \mathrm{~min}$ of the process, reaching equilibrium at around $20 \mathrm{~min}$, with $2.700 \mathrm{mg} \cdot \mathrm{g}^{-1}$ of AMX adsorbed (51\% removal). Maichin et al. (2013) found similar amounts of amoxicillin adsorption employing

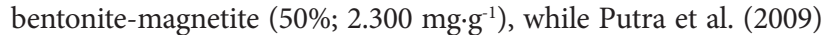
obtained higher adsorption rates using bentonite $(88 \% ; 9.300$ $\mathrm{mg} \cdot \mathrm{g}^{-1}$ ) and activated carbon Norit ROW (95\%; $\left.10.000 \mathrm{mg} \cdot \mathrm{g}^{-1}\right)$, and Zha et al. (2013) achieved $82 \%$ removal (21.600 mg.g when testing Na-montmorillonite.

Equilibrium for the process was considered to be reversible and fast, as a result of the molecules being physically attached to the adsorbent, weakening the intermolecular interactions. These intermolecular interactions originate from the attraction of induced permanent dipoles without changes in atomic or molecular orbitals, known as Van der Waals adsorption (Farina et al., 1999).

The amount of AMX adsorbed per gram of EP at equilibrium was calculated by fitting kinetic models and was found to be very close to the experimental result $-2.701 \mathrm{mg} \cdot \mathrm{g}^{-1}$ for a pseudo-secondorder equation (Table 1).

The pseudo-second-order model assumes that the adsorption speed is directly proportional to the square of available adsorption sites, suggesting that surface reactions control the process. The kinetic behaviour of EP corroborates the findings of other studies on the adsorption of silver, copper, mercury, caesium, lead and manganese (Ghassabzadeh et al., 2010; Cabranes et al., 2018; Temel, 2018; Turp, 2018).

The adsorption equilibrium assay was proposed to establish a relation between the amount of AMX removed and its residual concentration, providing information about the maximum adsorption capacity of the EP. From Langmuir, Freundlich, and Sips isothermal models, the amount of AMX and supernatant concentration were evaluated, and the isothermal parameters and correlation coefficients are given in Fig. 5 and Table 2.

The Sips model gave the best fit to the experimental data $\left(r^{2}=0.988\right)$. The maximum AMX adsorption capacity of EP was $2.570 \mathrm{mg} \cdot \mathrm{g}^{-1}$. These results inferred that EP has heterogeneity in the adsorbent surface and the interactions between the adsorbed molecule were considered multilayer for low concentrations and monolayer for high concentrations (Foo and Hameed, 2010). The isotherm of the AMX adsorption process by EP was classified as Type $\mathrm{V}$, in which the adsorbent-adsorbate interaction is weak, as obtained with certain porous adsorbents (IUPAC, 1985).

The increase in temperature described a non-spontaneous $(\Delta \mathrm{G}>0)$ and endothermic process $\left(\Delta \mathrm{G}=\right.$ decrease; $\left.\Delta \mathrm{H}=27.045 \mathrm{~kJ} \cdot \mathrm{mol}^{-1}\right)$. According to Castellan (1986), adsorption processes with energy below $42 \mathrm{~kJ} \cdot \mathrm{mol}^{-1}$ may be considered as a physical adsorption. Thus, the results of this study indicate that the adsorption occurred by physisorption.

Due to significant changes in the FTIR results for EP after the adsorption process, our results confirm a physisorption process, as shown in Fig. 6.

Table 1. Kinetic parameters of $A M X$ adsorption process in EP

\begin{tabular}{|c|c|c|c|c|c|c|}
\hline \multicolumn{4}{|c|}{ Pseudo-first-order } & \multicolumn{3}{|c|}{ Pseudo-second-order } \\
\hline $\mathrm{qe}_{\text {experiment }}\left(\mathrm{mg} \cdot \mathrm{g}^{-1}\right)$ & $\mathrm{qe}_{\text {calculated }}\left(\mathrm{mg} \cdot \mathrm{g}^{-1}\right)$ & $\mathrm{K}_{1}\left(\min ^{-1}\right)$ & $R^{2}$ & $\mathrm{qe}_{\text {calculated }}\left(\mathrm{mg} \cdot \mathrm{g}^{-1}\right)$ & $\mathrm{K}_{2}\left(\mathrm{~g} \cdot \mathrm{mg}^{-1} \cdot \mathrm{min}^{-1}\right)$ & $R^{2}$ \\
\hline 2.700 & 0.103 & 0.004 & 0.017 & 2.701 & 19.823 & 0.999 \\
\hline
\end{tabular}

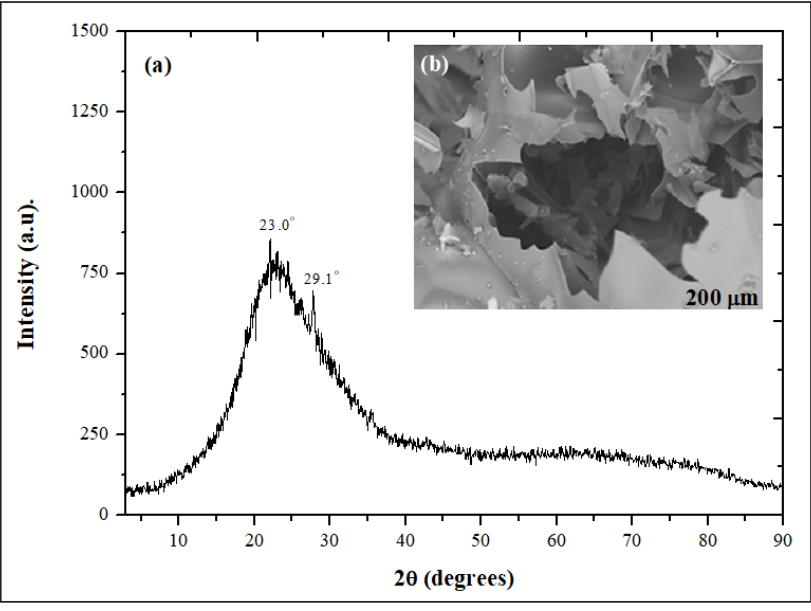

Figure 3. XRD pattern (a) of the EP. The inset (b) is an SEM image of the EP fracture

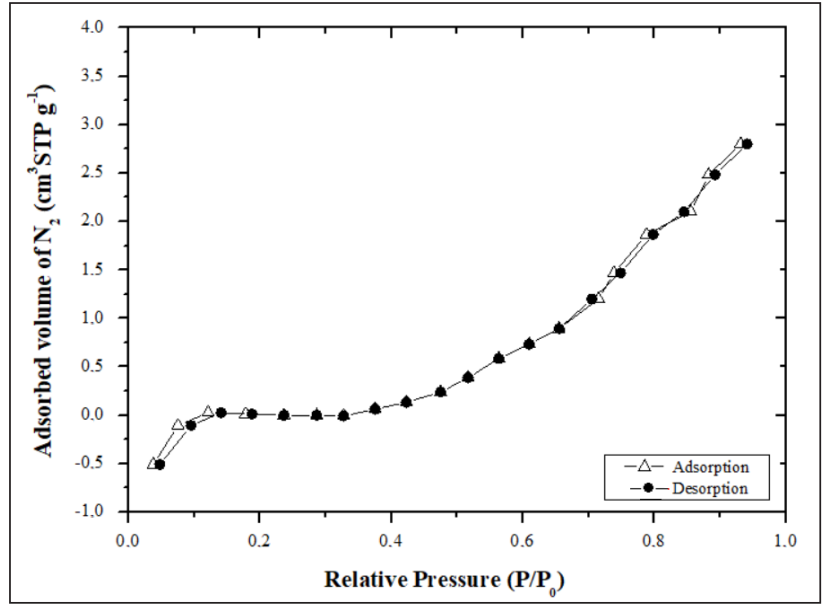

Figure 4. Adsorption/desorption $\mathrm{N}_{2}$ isotherms 
Table 2. Isotherm parameters of AMX adsorption process in EP

\begin{tabular}{|c|c|c|c|c|c|}
\hline Parameter & Unit & Value & $q_{\max }\left(\mathrm{mg} \cdot \mathrm{g}^{-1}\right)$ & $N$ & $r^{2}$ \\
\hline \multicolumn{6}{|c|}{ Langmuir } \\
\hline$k_{\mathrm{L}}$ & $L \cdot \mathrm{mg}^{-1}$ & 0.066 & 1.364 & & 0.882 \\
\hline \multicolumn{6}{|c|}{ Freundlich } \\
\hline$K_{\mathrm{F}}$ & $\mathrm{mg}^{1-(1 / n)} \cdot \mathrm{g}^{-1} \cdot \mathrm{L}^{1 / n}$ & 0.037 & & 0.514 & 0.828 \\
\hline \multicolumn{6}{|c|}{ Sips } \\
\hline$k_{\mathrm{s}}$ & $\left(L \cdot g^{-1}\right)^{1 / n}$ & 0.001 & 2.570 & 0.001 & 0.988 \\
\hline
\end{tabular}

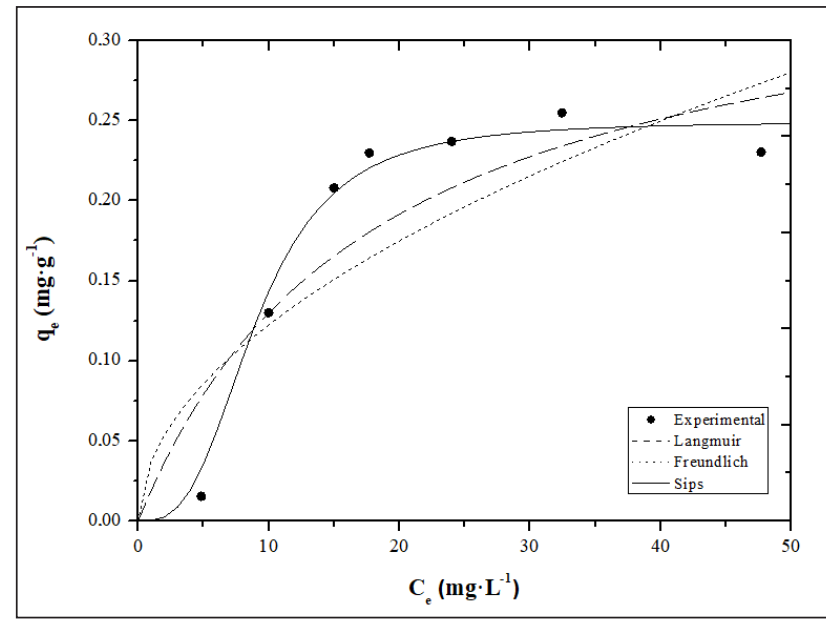

Figure 5. Langmuir, Freundlich, and Sips isotherms models for adsorption of AMX onto EP

Since the process of AMX adsorption by EP was set as physisorption, there were no major variations in the functional groups of the adsorbent (Fig. 6a). The broadening and shifting in the region of $3700-3300 \mathrm{~cm}^{-1}$ (Fig. 6b) was attributed to hydrogen bonds between -OH groups of EP and the hydrogen of hydroxyl and amino groups of AMX, which was also described by Ul Ain et al. (2018). Thus, for EP, there was no confirmation of modifications of functional groups, as is expected for physical adsorption, corroborating in part the results of the adsorption tests performed.

\section{CONCLUSIONS}

In seeking new materials for drug removal to reduce operating costs, it was necessary to study the degree of affinity between AMX and EP, in order to obtain an active and efficient adsorbent. Considering that considerable further research involving EP as adsorbent for drug removal is still required, the results obtained in this work indicate EP as a promising material for AMX removal by adsorption. The EP showed favourable physical-chemical characteristics, such as neutral isoelectric point, amorphous characteristics, and a physical adsorption process, which allows for it to be recycled for further use.. Nonetheless, some other variables should be further explored to improve the ability of EP to remove AMX, such as chemical composition, mass quantity and particle size of EP, $\mathrm{pH}$ variation of the solution, desorption, and reuse.

\section{ACKNOWLEDGEMENTS}

This paper was financially supported by CAPES. The authors are grateful to UFPR-Curitiba and UTFPR Analysis Center.

\section{REFERENCES}

ALI I, AL-OTHMAN ZA and ALWARTHAN A (2016) Synthesis of composite iron nano adsorbent and removal of ibuprofen drug residue from water. J. Mol. Liq. 219 858-864. https://doi. org/10.1016/j.molliq.2016.04.031

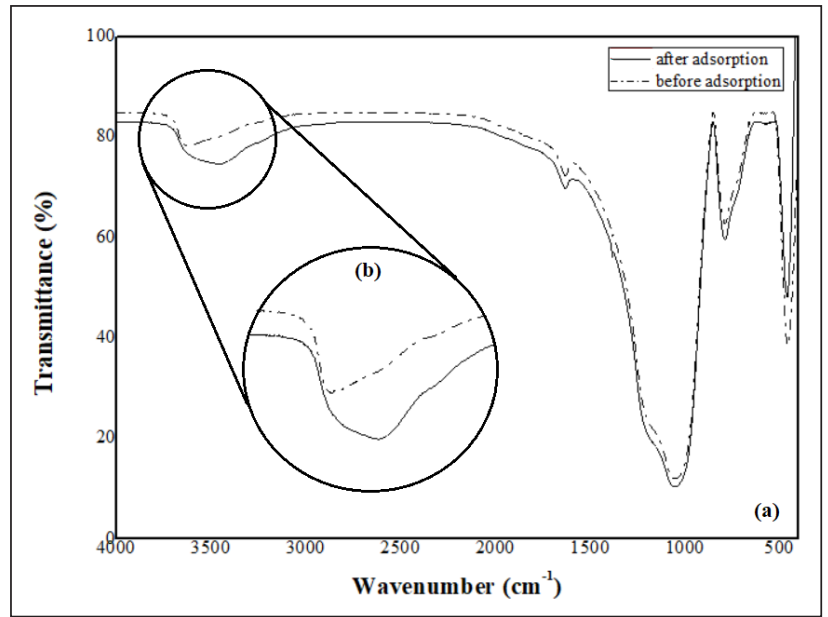

Figure 6. (a) FTIR of EP before (dotted line) and after (solid line) adsorption process; (b) magnification in the $3300-3900 \mathrm{~cm}^{-1}$ region

ALKAN M, DEMIRBAŞ Ö, DOĞAN M and ARSLAN O (2006) Surface properties of bovine serum albumin - adsorbed oxides: Adsorption, adsorption kinetics and electrokinetic properties. Micropor. Mesopor. Mater. 96 (1-3) 331-340. https://doi.org/10.1016/j.micro meso.2006.07.007

ALKAN M and DOGAN M (2002) Encyclopedia of Surface and Colloid Science. Marcel Dekker, New York. 897 pp.

ALKAN M, KARADAȘ M, DOĞAN M and DEMIRBAŞ Ö (2005) Adsorption of CTAB onto perlite samples from aqueous solutions. J. Colloid Interface Sci. 291 (2) 309-318. https://doi.org/10.1016/j. jcis.2005.05.027

ALMEIDA JMF, OLIVEIRA ES, SILVA IN, DE SOUZA SPMC and FERNANDES NS (2017) Adsorption of erichrome black $\mathrm{T}$ from aqueous solution onto expanded perlite modified with orthophenanthroline. Rev. Virtual Quim. 9 (2) 502-513. https://doi. org/10.21577/1984-6835.20170029

BLANCHARD G, MAUNAYE M and MARTIN G (1984) Removal of heavy metals from waters by means of natural zeolites. Water Res. 18 (12) 1501-1507. https://doi.org/10.1016/0043-1354(84)90124-6

CABRANES M, LEYVA AG and BABAY PA (2018) Removal of $\mathrm{Cs}^{+}$ from aqueous solutions by perlite. Environ. Sci. Pollut. Res. $221982-$ 21992. https://doi.org/10.1007/s11356-018-2283-9

CABUK M, YESIL TA and YAVUZ M (2018) Colloidal and viscoelastic properties of expanded perlite dispersions. J. Intell. Mater. Syst. Struct. 29 (1) 32-40. https://doi.org/10.1177/1045389X17698248

CASTELLAN GW (1986) Fundamentos de físico-química. LTC, Rio de Janeiro. 552 pp.

CELIK AG, KILIC AM and CAKAL GO (2013) Expanded perlite aggregate characterization for use as a lightweight construction raw material. Physicochem. Probl. Miner. Process. 49 (2) 689-700. https:// doi.org/10.5277/ppmp130227

CORREGIDOR PF, CUESTA PM, ACOSTA DE and DESTÉFANIS HA (2019) Composite ZSM-5/MCM-41 material obtained from a green resource and its enhanced catalytic performance in the reaction of vinyl acetate and isoamyl alcohol Appl. Catal. A-Gen. 587117262. https://doi.org/10.1016/j.apcata.2019.117262

DA SILVA FILHO SH, VINACHES P and PERGHER SB (2018) Zeolite synthesis in basic media using expanded perlite and its application in Rhodamine B adsorption. Mater. Lett. 227 258-260. https://doi. org/10.1016/j.matlet.2018.05.095 
DE OLIVEIRA AG, JANDORNO JC, DA ROCHA EBD, DE SOUSA AMF and DA SILVA ALN (2019) Evaluation of expanded perlite behavior in PS/Perlite composites. Appl. Clay Sci. 181105223. https://doi.org/10.1016/j.clay.2019.105223

DÍEZ AM, PAZOS M and SANROMÁN MA (2020) Bifunctional floating catalyst for enhancing the synergistic effect of LEDphotolysis and electro-Fenton process. Sep. Purif. Technol. 230 115880. https://doi.org/10.1016/j.seppur.2019.115880

DUBE C, TANDLICH R and WILHELMI B (2018) Adsorptive removal of ciprofloxacin and isoniazid from aqueous solution. Nov. Biotechnol. et Chim. 17 (1) 16-28. https://doi.org/10.2478/nbec-2018-0002

FARINA C, SANTOS FC and TORT AC (1999) A simple way of understanding the nonadditivity of Van der Waals dispersion forces. Am. J. Phys. 67 (4) 344-349.

FOO KY, HAMEED BH (2010) Insights into the modeling of adsorption isotherm systems. Chem. Eng. J. 156 (1) 2-10. https://doi. org/10.1016/j.cej.2009.09.013

FREUNDLICH H (1909) The theory of adsorption. Z. Phys. Chem. $3212-220$.

GHASSABZADEH H, MOHADESPOUR A, TORAB-MOSTAEDI M, ZAHERI P, GHANNADI M and TAHERI H (2010) Adsorption of $\mathrm{Ag}, \mathrm{Cu}$ and $\mathrm{Hg}$ from aqueous solutions using expanded perlite. J. Hazardous Mater. 177 (1-3) 950-955. https://doi.org/10.1016/j. jhazmat.2010.01.010

GITHINJI LJM, MUSEY MK and ANKUMAH RO (2011) Evaluation of the fate of ciprofloxacin and amoxicillin in domestic wastewater. Water Air Soil Pollut. 219 191-201. https://doi.org/10.1007/s11270 010-0697-1

HAN R, ZHANG J, ZOU W, SHI J and LIU H (2005) Equilibrium biosorption isotherm for lead ion on chaff. J. Hazardous Mater. 125 (1-3) 266-271. https://doi.org/10.1016/j.jhazmat.2005.05.031

HEYDARTAEMEH M, DOULATI ARDEJANI F, BADII K, SEIFPANAHI SHABANI K and MOUSAVI S (2014) $\mathrm{FeCl}_{2} / \mathrm{FeCl}_{3}$ perlite nanoparticles as a novel magnetic material for adsorption of green malachite dye. Arab. J. Sci. Eng. 39 3383-3392. https://doi. org/10.1007/s13369-014-0978-x

IUPAC (1985) Reporting physisorption data for gas/solid systems with special reference to the determination of surface area and porosity. Pure Appl. Chem. 54 (11) 2201-2218.

JIANG L, JIA G, JIANG C and LI Z (2020) Sugar-coated expanded perlite as a bacterial carrier for crack-healing concrete applications. Constr. Build. Mater. 232 117222. https://doi.org/10.1016/j.conbuild mat.2019.117222

LANGMUIR I (1916) The constitution and fundamental properties of solids and liquids. J. Am. Chem. Soc. 38 (11) 2221-2295. https://doi. org/10.1021/ja02268a002

LEYTON-VERGARA M, PÉREZ-FARGALLO A, PULIDO-ARCAS J, CÁRDENAS-TRIVIÑO G and PIGGOT-NAVARRETE J (2019) Influence of granulometry on thermal and mechanical properties of cement mortars containing expanded perlite as a lightweight aggregate. Materials (Basel). 12 (23) 4013. https://doi.org/10.3390/ ma12234013

LIU C, MA Q, HE H, HE G, MA J, LIU Y and WU Y (2017) Structureactivity relationship of surface hydroxyl groups during $\mathrm{NO}_{2}$ adsorption and transformation on $\mathrm{TiO}_{2}$ nanoparticles. Environ. Sci. Nano. 4 (12) 2388-2394. https://doi.org/10.1039/c7en00920h

LUO Z, FAN, S, LIU J, LIU W, SHEN X, WU C, HUANG Y, HUANG G, HUANG H and ZHENG M (2018) A 3D stable metal-organic framework for highly efficient adsorption and removal of drug contaminants from water. Polymers. 10 (2) 209. https://doi.org/ 10.3390/polym 10020209

MA B, JIN Z, SU Y, LU W, QI H and HU P (2020) Utilization of hemihydrate phosphogypsum for the preparation of porous sound absorbing material. Constr. Build. Mater. 234 117346. https://doi. org/10.1016/j.conbuildmat.2019.117346

MAICHIN F, FREITAS LC and ORTIZ N (2013) The use of converter slag (magnetite) and bentonite clay for amoxicillin adsorption from polluted water. Orbital: Eletron. J. Chem. 5 (3) 1-5. https://doi. org/10.17807/orbital.v5i3.494

MOUSSAVI G and BAGHERI A (2012) Removal of petroleum hydrocarbons from contaminated groundwater by the combined technique of adsorption onto perlite followed by the $\mathrm{O}_{3} / \mathrm{H}_{2} \mathrm{O}_{2}$ process. Environ. Technol. 33 (16) 1905-1912. https://doi.org/10.10 $80 / 09593330.2011 .650223$
MULLET M, FIEVET P, REGGIANI JC and PAGETTI J (1997) Surface electrochemical properties of mixed oxide ceramic membranes "Zeta-potential and surface charge density. J. Membr. Sci. 123 (2) 255-265. https://doi.org/10.1016/S0376-7388(96)00220-7

NASROLLAHZADEH M, SAJADI SM, ROSTAMI-VARTOONI A, BAGHERZADEH $M$ and SAFARI R (2015) Immobilization of copper nanoparticles on perlite: Green synthesis, characterization and catalytic activity on aqueous reduction of 4-nitrophenol. J. Mol. Catal. A-Chem. 400 22-30. https://doi.org/10.1016/j.molcata. 2015.01.032

PAPA E, MEDRI V, MURRI A, LAGHI L, DE ALOYSIO G, BANDINI $S$ and LANDI E (2018) Characterization of alkali bonded expanded perlite. Constr. Build. Mater. 191 1139-1147. https://doi.org/10.1016/j. conbuildmat.2018.10.086

PUTRA EK, PRANOWO R, SUNARSO J, INDRASWATI N and ISMADJI S (2009) Performance of activated carbon and bentonite for adsorption of amoxicillin from wastewater: mechanisms, isotherms and kinetics. Water Res. 43 (9) 2419-2430. https://doi. org/10.1016/j.watres.2009.02.039

RATHORE PKS, SHUKLA SK and GUPTA NK (2020) Synthesis and characterization of the paraffin/expanded perlite loaded with graphene nanoparticle as a thermal energy storage material in buildings. J. Sol. Energy Eng. 142 (4) 041006. https://doi.org/ $10.1115 / 1.4046087$

RODRIGUEZ J, SORIA F, GERONAZZO H and DESTEFANIS H (2016) Modification and characterization of natural aluminosilicates, expanded perlite, and its application to immobilise $\alpha$-amylase from A. oryzae. J. Mol. Catal. B Enzym. 133 (1) S259-S270. https://doi. org/10.1016/j.molcatb.2017.01.012

SILBER A, BAR-YOSEF B, SURYANO S and LEVKOVITCH I (2012) Zinc adsorption by perlite: Effects of $\mathrm{pH}$, ionic strength, temperature, and pre-use as growth substrate. Geoderma. 170 159-167. https:// doi.org/10.1016/j.geoderma.2011.11.028

SIPS R (1948) On the structure of a catalyst surface. J. Chem. Phys. 16 490-495. https://doi.org/10.1063/1.1746922

TEMEL FA (2018) Endüstriyel sızıntı suyundan $\mathrm{Pb}$ (ii) giderimi için genleştirilmiş perlit Kullanımı: Kinetik çalışmalar. Türk Tarım Gıda Bilim ve Teknol. Derg. 6 (3) 360-364. https://doi.org/10.24925/ turjaf.v6i3.360-364.1748

TIAN Y, TANG Y, LI S, LV H, LIU P and JING Q (2019) Voigt-based swelling water model for super water absorbency of expanded perlite and sodium polyacrylate resin composite materials. E-Polymers. 19 (1) 365-368. https://doi.org/10.1515/epoly-2019-0038

TOP S, VAPUR H, ALTINER M, KAYA D and EKICIBIL A (2020) Properties of fly ash-based lightweight geopolymer concrete prepared using pumice and expanded perlite as aggregates. J. Mol. Struct. 1202 127236. https://doi.org/10.1016/j.molstruc.2019.127236

TORAB-MOSTAEDI M, GHAEMI A, GHASSABZADEH $\mathrm{H}$ and GHANNADI-MARAGHEH M (2011) Removal of strontium and barium from aqueous solutions by adsorption onto expanded perlite. Can. J. Chem. Eng. 89 (5) 1247-1254. https://doi.org/10.1002/ cjce. 20486

TORAB-MOSTAEDI M, GHASSABZADEH H, GHANNADIMARAGHEH M, AHMADI SJ and TAHERI H (2010) Removal of cadmium and nickel from aqueous solution using expanded perlite. Braz. J. Chem. Eng. 27 (2) 299-308. https://doi.org/10.1590/S010466322010000200008

TURP S (2018) $\mathrm{Mn}^{2+}$ and $\mathrm{Cu}^{2+}$ adsorption with a natural adsorbent: Expanded perlite. Appl. Ecol. Env. Res. 16 (4) 5047-5057. https://doi. org/10.15666/aeer/1604_50475057

UL AIN N, ANIS I, AHMED F, SHAH MR, PARVEEN S, FAIZI S and AHMED S (2018) Colorimetric detection of amoxicillin based on querecetagetin coated silver nanoparticles. Sensor Actuat B-Chem. 265 617-624. https://doi.org/10.1016/j.snb.2018.03.079

VILLASEÑOR J, RODRÍGUEZ L and FERNÁNDEZ J (2011) Composting domestic sewage sludge with natural zeolites in a rotary drum reactor. Bioresour. Technol. 102 (2) 1447-1454. https:// doi.org/10.1016/j.biortech.2010.09.085

WHO (2014) Antimicrobial Resistance: Global Report on Surveillance. World Health Organization, Geneva. 256 pp.

YENER J, KOPAC T, DOGU G and DOGU T (2006) Adsorption of basic yellow 28 from aqueous solutions with clinoptilolite and amberlite. J. Colloid Interface Sci. 294 (2) 255-264. https://doi.org/10.1016/j. jcis.2005.07.040 
YU K, LI P, CHEN Y, ZHANG B, HUANG Y, HUANG FY and HE Y (2020) Antibiotic resistome associated with microbial communities in an integrated wastewater reclamation system. Water Res. 173 115541. https://doi.org/10.1016/j.watres.2020.115541
ZHA SX, ZHOU Y, JIN X and CHEN Z (2013) The removal of amoxicillin from wastewater using organobentonite. J. Environ. Manage. 129 569-576. https://doi.org/10.1016/j.jenvman.2013.08.032 